\title{
ANALISIS KEMAMPUAN AWAL LITERASI SAINS PADA MAHASISWA TINGKAT PERTAMA TERHADAP KONSEP BIOLOGI DASAR
}

\author{
Agung Wibowo \\ Institut Teknologi dan Sains Nahdlatul Ulama Pasuruan (ITSNU) \\ e-mail: aweagung412@gmail.com
}

\begin{abstract}
Abstrak: Penelitian bertujuan mendeskripsikan kemampuan awal literasi sains pada mahasiswa tingkat awal. Pengukuran kemampuan literasi sains yang disusun mengacu pada kompetensi Problem Solving dan Decision Making. Penelitian ini termasuk penelitian deskriptif kuantitatif. Penelitian dilakukan pada 15 mahasiswa jurusan S1 Pendidikan Biologi Institut Teknologi dan Sains Nahdlatul Ulama (ITSNU) Pasuruan. Instrumen penelitian menggunakan soal uraian berdasarkan skala literasi yang dikembangkan oleh Bybee (1997). Data hasil penelitian dikumpulkan dari hasil penskoran jawaban mahasiswa terhadap masalah yang diajukan secara tertulis. Hasil penelitian menunjukkan kemampuan literasi sains mahasiswa terhadap konsep biologi dasar untuk kedua kompetensi didominasi kategori nominal dengan rentang persentase $62 \%$ - $80 \%$, sebagian kecil pada kategori fungsional sebesar $13 \%$ - $34 \%$. Pada kategori konseptual berada pada rentang $4 \%$ $7 \%$ dan multidimensional sebesar $0 \%$. Hasil yang diperoleh sesuai dengan penelitian sebelumnya yang menyatakan bahwa kemampuan literasi sains sebagian besar berada pada tingkatan rendah.
\end{abstract}

Kata kunci: literasi sains, nominal, fungsional, prosedural \& multidimensional

\begin{abstract}
The study aims to describe the initial ability of scientific literacy in earlylevel students. Measurements of scientific literacy skills compiled refer to the competence of Problem Solving and Decision Making. This research includes quantitative descriptive research. The study was conducted on 15 students majoring in Biology Education at the Institute of Technology and Science at Nahdlatul Ulama (ITSNU) Pasuruan. The research instrument uses description questions based on the literacy scale developed by Bybee (1997). Data from research results are collected from the results of scoring students' answers to the problems submitted in writing. The results show that students' scientific literacy skills towards the basic biology concept for both competencies are dominated by nominal categories with a percentage range of $62 \%-80 \%$, a small portion in the functional category of $13 \%$ $34 \%$. The conceptual category is in the range of $4 \%-7 \%$ and multidimensional at $0 \%$. The results obtained are in accordance with previous studies which state that scientific literacy skills are mostly at low levels.
\end{abstract}

Keywords: scientific literacy, nominal, functional, conceptual \& multidimensional 


\section{PENDAHULUAN}

Keterampilan literasi sains harus dimiliki oleh seseorang dalam menjalankan segala aktivitas. Pada abad ke-21, ilmu akan memiliki dampak yang besar pada kualitas kehidupan pribadi, lingkungan, dan ekonomi dunia, sehingga diharapkan peserta didik memiliki literasi sains yang tinggi (Glynn \& Muth, 1994). Sejauh ini diketahui bahwa literasi sains mahasiswa tingkat sarjana tidak jauh berbeda dengan literasi masyarakat pada umumnya dan hanya berbeda 10-15\% dari mahasiswa pascasarjana (Impey et al., 2011), sehingga dapat dikatakan bahwa tingginya jenjang pendidikan belum bisa menentukan tinggi atau rendahnya tingkat literasi sains seseorang.

Sebuah langkah penting dalam membantu para peserta didik untuk mencapai keterampilan literasi sains yang cukup tinggi yaitu memastikan bahwa kurikulum sekolah masing-masing mendukung upaya peserta didik untuk belajar ilmu bermakna. Pelaku pendidikan memainkan peran penting dalam langkah ini dengan menyediakan guru, pendidik guru, administrator, dan pembuat kebijakan dengan informasi tentang pengembangan kurikulum yang mendukung literasi sains (Hurd, 1997).

Literasi sains merupakan istilah luas yang menggabungkan ide ilmiah dan konsep pada berbagai disiplin ilmu serta praktik ilmiah (DeBoer, 2000; Shwartz et $a l ., 2006)$. Usaha yang dilakukan dalam rangka memahami berbagai komponen literasi sains salah satunya dengan cara menyelidiki komponen literasi dalam berbagai mata pelajaran (Shwartz et al., 2006) seperti literasi biologi. Literasi biologi didefinisikan sebagai pemahaman prinsip biologi dan aplikasinya ketika membaca sebuah berita, diskusi, mencari informasi yang valid, menginterpretasikan tabel dan gambar, serta membuat keputusan secara pribadi maupun bersama-sama (Demastes \& Wandersee, 1992; Miller, 2011). Literasi biologi berhubungan dengan perolehan sikap, keterampilan, dan pengetahuan biologi yang memungkinkan seseorang untuk berpartisipasi dalam sebuah permaslahan biologi. Melalui permasalahan biologi diharapkan seseorang mampu mengembangkan keterampilan memecahkan masalah dan pengambilan keputusan dalam kehidupan sehari-hari (Uno \& Bybee, 1994; Miller, 2011). Dibandingkan dengan pengetahuan fisika, literasi biologi dapat berdampak lebih langsung terhadap kehidupan pribadi seseorang (Klymkowsky et al., 2003).

Penelitian mengenai penilaian literasi kimia pada Sekolah Menengah Atas menggunakan skala yang dikembangkan oleh Bybee (1997) menyimpulkan bahwa semua siswa memiliki tingkatan literasi nominal dan fungsional dengan sangat baik, tetapi hanya sebagian siswa yang mampu berada pada tingkatan konseptual dan multidimensional (Shwartz et al., (2006). Pada penelitian ini bertujuan untuk mendeskripsikan kemampuan literasi sains mahasiswa pada tingkat awal dengan mengacu pada kategori nominal. Fungsional, konseptual, dan multidimensional. 
Agung Wibowo - Analisis Kemampuan Awal Literasi Sains pada Mahasiswa Tingkat Pertama Terhadap Konsep Biologi Dasar

\section{TINJAUAN PUSTAKA}

Literasi sains adalah sebuah aplikasi pemahaman konseptual yang luas dari ilmu pengetahuan untuk memahami dunia, memahami fenomena alam, dan menafsirkan laporan media tentang isu ilmiah, hal ini juga termasuk mengajukan pertanyaan, melakukan investigasi, mengumpulkan dan menafsirkan data dan membuat keputusan (OECD, 2013). Literasi sains juga didefiniskan sebagai kemampuan untuk berpikir secara ilmiah dan kritis, mampu menggunakan pengetahuan ilmiah untuk mengembangkan keterampilan membuat keputusan (Holbrook \& Rannikmae, 2009). Pendapat lain menjelaskan bahwa literasi sains adalah pengetahuan yang berhubungan dengan fenomena alam yang harus dimiliki oleh seseorang untuk diterapkan ke dalam kehidupannya (DeBoer, 2000). Melalui berbagai definisi ini dapat disimpulkan bahwa literasi sains adalah kemampuan untuk menggambarkan, menjelaskan, memprediksi fenomena alam yang terjadi dan mencari alternatif solusi permasalahan tersebut melalui berbagai kegiatan. Penggambaran skematis literasi sains disajikan pada Gambar 1 berikut.

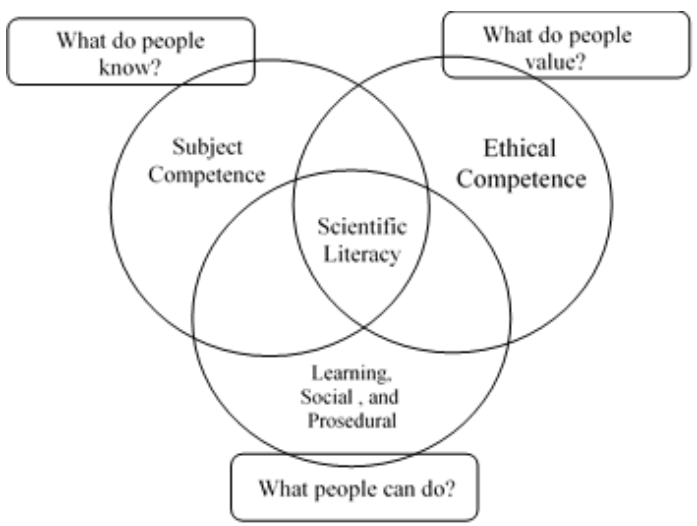

Gambar 1 Skema Model Literasi Sains

(Holbrook \& Rannikmae, 2009)

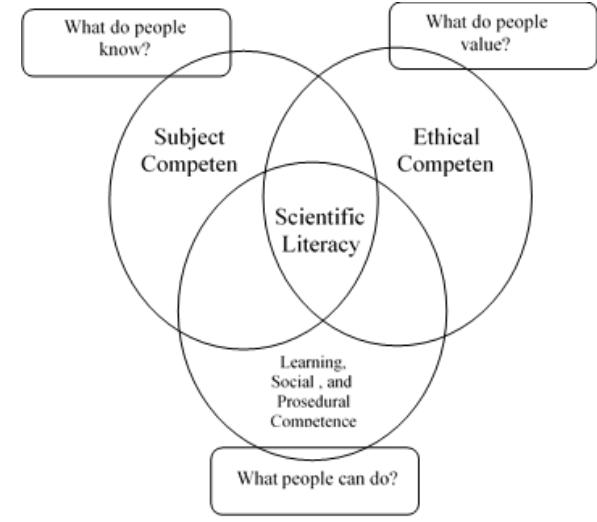

Skala literasi digunakan agar lebih mudah mengukur tingkatan kemampuan literasi siswa. Skala teoritis komprehensif yang digunakan lebih cocok untuk penilaian literasi sains selama menempuh pendidikan, karena tingkatan hierarki dapat dengan mudah ditransfer pada tujuan pembelajaran (Bybee, 1997). Pada penelitian ini juga menggunakan skala literasi yang sama. Skala literasi sains disajikan pada Tabel 1 berikut.

Tabel 1 Skala Literasi Sains

\begin{tabular}{|l|l|l|}
\hline No & \multicolumn{1}{|c|}{ Skala } & \multicolumn{1}{c|}{ Keterangan } \\
\hline 1 & $\begin{array}{l}\text { Nominal } \\
\text { scientific } \\
\text { literacy }\end{array}$ & $\begin{array}{l}\text { Siswa mengenal konsep } \\
\text { yang terkait dengan } \\
\text { sains, namun tingkat } \\
\text { pemahaman } \\
\text { menunjukkan } \\
\text { kesalahpahaman } \\
\text { (miskonsepsi) }\end{array}$ \\
\hline 2 & $\begin{array}{l}\text { Functional } \\
\text { scientific } \\
\text { literacy }\end{array}$ & $\begin{array}{l}\text { Siswa dapat menjelaskan } \\
\text { konsep dengan benar, } \\
\text { tetapi memiliki } \\
\text { pemahaman yang hanya } \\
\text { sebatas itu. }\end{array}$ \\
\hline 3 & $\begin{array}{l}\text { Conceptual } \\
\text { scientific } \\
\text { literacy }\end{array}$ & $\begin{array}{l}\text { Siswa mengembangkan } \\
\text { beberapa pemahaman } \\
\text { tentang skema } \\
\text { konseptual utama dan } \\
\text { menghubungkan skema } \\
\text { untuk pemahaman } \\
\text { umum mereka mengenai } \\
\text { sains. } \\
\text { Siswa memiliki } \\
\text { kemampuan prosedural } \\
\text { dan pemahaman tentang }\end{array}$ \\
\hline
\end{tabular}




\begin{tabular}{|c|c|c|}
\hline No & Skala & Keterangan \\
\hline & & $\begin{array}{l}\text { proses inkuiri ilmiah dan } \\
\text { desain teknologi. }\end{array}$ \\
\hline 4 & $\begin{array}{l}\text { Multidimensi } \\
\text { onal } \\
\text { scientific } \\
\text { literacy }\end{array}$ & $\begin{array}{l}\text { Siswa menggabungkan } \\
\text { pemahaman sains yang } \\
\text { melampaui konsep } \\
\text { disiplin ilmu dan } \\
\text { prosedur investigasi } \\
\text { saintifik. Mencakup } \\
\text { dimensi filosofis, } \\
\text { historis, dan sosial dari } \\
\text { ilmu pengetahuan dan } \\
\text { teknologi. } \\
\text { Siswa mengembangkan } \\
\text { beberapa pemahaman } \\
\text { dan apresiasi terhadap } \\
\text { sains dan teknologi } \\
\text { mengenai hubungannya } \\
\text { dengan kehidupan } \\
\text { sehari-hari mereka. } \\
\text { Mereka mampu } \\
\text { membuat koneksi dalam } \\
\text { disiplin ilmu antara } \\
\text { sains, teknologi, dan isu- } \\
\text { isu yang besar serta } \\
\text { menantang di } \\
\text { masyarakat. }\end{array}$ \\
\hline
\end{tabular}

(Shwartz et al., 2006)

\section{METODE}

Jenis penelitian ini merupakan penelitian deskriptif kuantitatif yang bertujuan menggambarkan secara cermat dan sistematis mengenai fakta dan sifat populasi tertentu. Jenis penelitian digunakan untuk mendeskripsikan kemampuan awal literasi sains mahasiswa pada kategori nominal, fungsional, konseptual, dan multidimensional (Shwartz et al., 2006). Penelitian dilakukan di Jurusan S1 Pendidikan Biologi Institut Teknologi dan Sains Nahdlatul Ulama (ITSNU) Pasuruan.

Data hasil penelitian dikumpulkan dari hasil penskoran jawaban mahasiswa terhadap masalah yang diajukan secara tertulis. Hasil penskoran jawaban dikategorikan ke dalam 4 jenis yaitu nominal, fungsional, konseptual, dan multidimensional, kemudian dipersentase sesuai kategori di atas. Objek penelitian adalah 15 mahasiswa semester 2 tahun ajaran 2018/2019 dan dilaksanakan pada bulan Januari 2019.

\section{HASIL DAN PEMBAHASAN}

Hasil tes menunjukkan bahwa kemampuan literasi sains mahasiswa biologi sebagian besar berada pada kategori pertama yaitu nominal dan hanya sebagian kecil pada kategori fungsional dan konseptual. Pengukuran menggunakan indikator kompetensi problem solving dan decision making dengan tema fenomena alam yang terjadi di sekitar. Grafik pengukuran kemampuan literasi mahasiswa pada kompetensi problem solving disajikan pada Gambar 2 berikut.

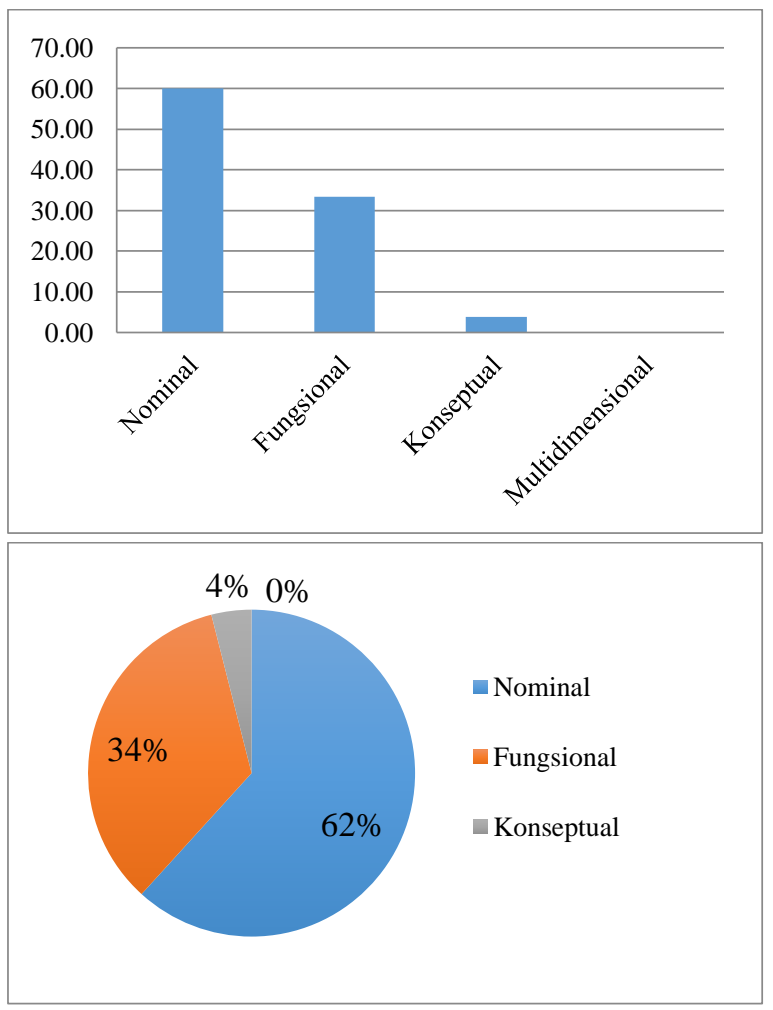

Gambar 2 Persentase Kemampuan Literasi Mahasiswa pada Kompetensi Problem Solving 
Agung Wibowo - Analisis Kemampuan Awal Literasi Sains pada Mahasiswa Tingkat Pertama Terhadap Konsep Biologi Dasar

Hasil persentase literasi sains mahasiswa pada kasus pertama dengan kompetensi problem solving menunjukkan persentase paling tinggi berada pada kategori nominal yaitu sebesar $62 \%$. Pada kategori fungsional sebesar $34 \%$, dan hanya $4 \%$ yang berada pada kategori konseptual. Hasil pengukuran kemampuan literasi tidak ada satupun mahasiswa yang mampu berada pada kategori multidimensional $(0 \%)$.

Hasil pengukuran kemampuan literasi sains mahasiswa pada kompetensi kedua tidak jauh berbeda. Literasi sains mahasiswa masih didominasi pada kategori nominal dan fungsional. Grafik pengukuran kemampuan literasi mahasiswa pada kompetensi decision making disajikan pada Gambar 1.3 berikut.

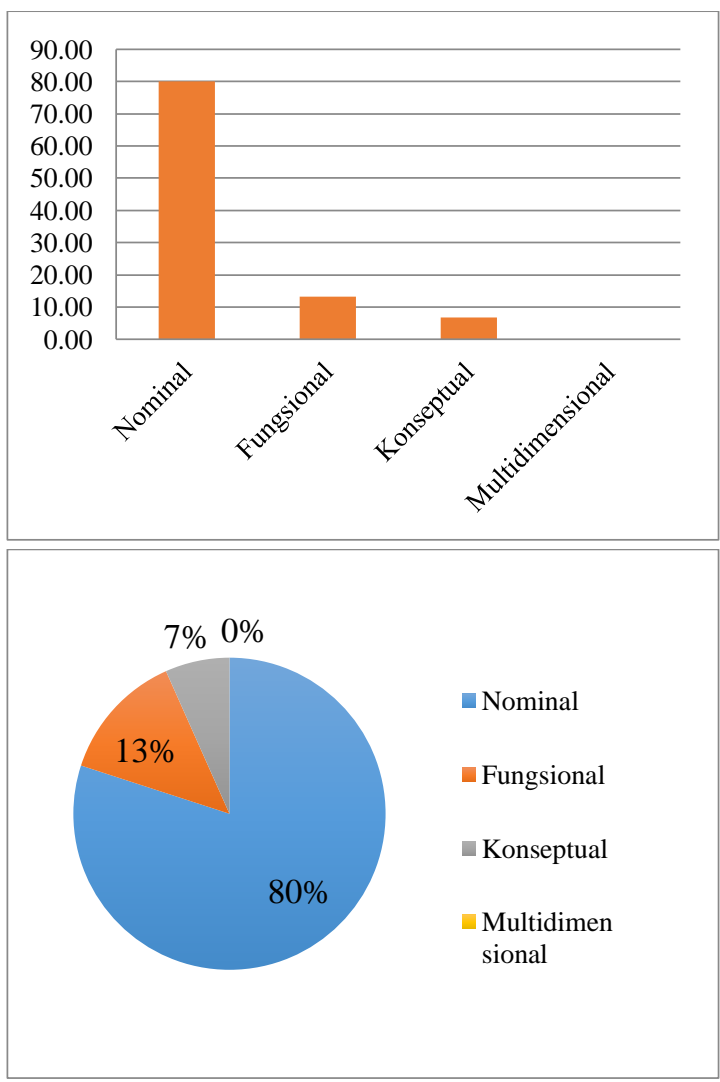

Gambar 1.3 Persentase Kemampuan Literasi Mahasiswa pada Kompetensi Decision Making
Hasil persentase literasi sains mahasiswa pada kasus kedua dengan kompetensi decision making menunjukkan persentase paling tinggi berada pada kategori nominal yaitu sebesar $80 \%$. Pada kategori fungsional sebesar $13 \%$, dan hanya $7 \%$ berada pada kategori konseptual. Hasil pengukuran kemampuan literasi tidak ada satupun mahasiswa yang mampu berada pada kategori multidimensional (0\%). Hal ini menunjukkan bahwa mahasiswa masih belum mampu memanfaatkan konsep antar disiplin ilmu serta menunjukkan pemahaman dan saling keterkaitan. Mahasiswa juga belum memiliki pemahaman tentang masalah, membenarkan jawaban dengan benar informasi dari teks, grafik atau tabel. Mahasiswa tidak mampu menganalisis alternatif solusi secara tepat berdasarkan fakta ilmiah.

Berdasarkan hasil jawaban mahasiswa terhadap permasalahan yang disediakan menunjukkan bahwa secara umum tingkatan literasi mahasiswa tingkat pertama berada pada kategori rendah yaitu nominal. Kasus pertama menunjukkan bahwa mahasiswa tidak mampu menyelesaikan permasalahan yang terjadi. Mahasiswa hanya mampu menjelaskan solusi secara umum tanpa dapat memberikan penjelasan atau masalah secara runtut dan sesuai prosedur ilmiah. Pada kasus kedua mahasiswa hanya mampu memberikan keputusan terhadap fenomena yang terjadi, tanpa adanya ide-ide sendiri. Beberapa mahasiswa mampu memunculkan istilah ilmiah tetapi tingkat pemahaman menunjukkan kesalahan atau miskonsepsi. 
Beberapa mahasiswa mampu memberikan penjelasan pada kategori fungsional, hal ini dibuktikan dari penjelasan jawaban yang merujuk pada pendapat sendiri dengan menuliskan fakta-fakta dasar yang mungkin mereka dapat dari buku-buku teks. Tetapi mahasiswa masih belum mampu membenarkan pendapat sendiri berdasarkan pada teks atau grafik yang diberikan. Mahasiswa mungkin juga mengetahui konsep antar disiplin, tetapi tidak mampu menggambarkan hubungan antara konsep-konsep tersebut.

Hasil ini menunjukkan bahwa terdapat pola pembelajaran yang tidak tepat selama menempuh pendidikan pada jenjang sekolah dasar dan menengah. Berdasarkan penelitian yang dilakukan oleh Shwartz et al., (2006) mengenai penilaian literasi kimia pada Sekolah Menengah Atas menggunakan skala yang dikembangkan oleh Bybee (1997) juga memiliki hasil serupa. Semua siswa hanya sebatas memiliki tingkatan literasi nominal dan fungsional, hanya sebagian siswa yang mampu berada pada tingkatan konseptual dan multidimensional. Kemampuan literasi sains harus dikembangkan dan dimulai sejak dini dengan mengenalkan banyak permasalahan ilmiah dan mencari alternatif solusi ilmiah berdasarkan faktafakta yang ditemukan.

Penelitian lain mengenai analisis awal kemampuan literasi sains siswa pada konsep IPA di Indonesia juga menunjukkan bahwa hanya dua tingkat kategori dari empat kategori literasi sains yang mampu dicapai yaitu nominal dan fungsional (Odja \& Payu, 2014). Soobard \& Rannikmäe (2011) juga menyimpulkan melalui hasil penelitian pada jenjang Sekolah Menengah Atas di negara Estonia menunjukkan bahwa kemampuan literasi sains siswa hanya sebatas fungsional dan sangat sedikit yang sampai pada tahap multidimensional. Hal ini sesuai dengan hasil penelitian yang dilakukan. Penggunaan skala literasi yang terdiri dari 4 skala ini digunakan agar lebih mudah mengukur tingkatan kemampuan literasi siswa. Skala teoritis komprehensif yang digunakan lebih cocok untuk penilaian literasi sains selama menempuh pendidikan, karena tingkatan hierarki dapat dengan mudah ditransfer pada tujuan pembelajaran (Bybee, 1997).

Hasil pengukuran literasi sains PISA pada tahun 2000-2009 menunjukkan bahwa tingkat literasi sains peserta didik Indonesia masih rendah. Indonesia menduduki peringkat 2 sampai 4 terbawah dari negara anggota OECD lain dengan rerata skor 393 (Balitbang, 2011). Berdasarkan data ini seharusnya pembelajaran harus menggabungkan pemahaman sains yang melampaui konsep disiplin ilmu dan prosedur investigasi saintifik. Mencakup dimensi filosofis, historis, dan sosial dari ilmu pengetahuan dan teknologi. Maka dengan cara seperti itu diharapkan mereka mampu mengembangkan beberapa pemahaman dan apresiasi terhadap sains dan teknologi mengenai hubungannya dengan kehidupan seharihari mereka. Mereka mampu membuat koneksi dalam disiplin ilmu antara sains, teknologi, dan isu-isu yang besar serta menantang di masyarakat (Shwartz et al., 2006). 
Agung Wibowo - Analisis Kemampuan Awal Literasi Sains pada Mahasiswa Tingkat Pertama Terhadap Konsep Biologi Dasar

\section{KESIMPULAN DAN SARAN}

Berdasarkan hasil analisis data dapat disimpulkan bahwa kemampuan literasi sains mahasiswa terhadap konsep biologi dasar berada pada kategori rendah yaitu nominal dengan rentang persentase $62 \%$ $80 \%$, sebagian kecil pada kategori fungsional dengan rentang persentase $13 \%$ - $34 \%$. Pada kategori konseptual berada pada rentang $4 \%$ - 7\% dan multidimensional berada pada persentase $0 \%$.

Disarankan bagi para pendidik untuk menerapkan metode dan strategi pembelajaran berbasis investigasi saintifik dengan cara menggabungkan pemahaman sains yang melampaui konsep disiplin ilmu dan prosedur ilmiah agar peserta didik terbiasa berpikir secara multidimensional yaitu mengaitkan antar disiplin ilmu, memahami masalah, membenarkan jawaban dari berbagai informasi teks, grafik, atau tabel, serta mampu menganalisis alternatis solusi yang tepat berdasarkan fakta ilmiah.

\section{DAFTAR PUSTAKA}

Balitbang. 2011. Survei Internasional PISA, (Online), (http://litbang.kemdikbud.go.id/ ), diakses 27 Oktober 2015.

Bybee, R.W. 1997. Achieving Scientific Literacy: from Purposes to Practices. Portsmouth, NH: Heinmann Publishing, pp. 8286.

DeBoer, G. E. 2000. Scientific Literacy: Another Look at Its Historical and Contemporary Meanings and Its Relationship to Science Education Reform. Journal of Research in Science Teaching, 37 (6): 582- 601.
Demastes, S. \& Wandersee, J. H. 1992. Biological Literacy in a College Biology Classroom. BioScience, 42 (1): 241-252.

Glynn, S. M. \& Muth, K. D. 1994.

Reading and Writing to Learn Science: Achieving Scientific Literacy. Journal of Research in Science Teaching, 31 (9): 1057 1073.

Holbrook, J. \& Rannikmae, M. 2009 The Meaning of Scientific Literacy. International Journal of Environmental \& Science Education, 4 (3): 275-288.

Hurd, P. D. 1997. Scientific Literacy: New Minds for a Changing World. Science Education, 82 (3): 407-416.

Impey, C., Buxner, S., Antonellis J., Johnson E. \& King, C. 2011. A Twenty-Year Survey of Science Literacy Among College Undergraduates. Journal of College Science Teaching. 40 (4): $31-37$

Klymkowsky, M. W., Garvin-Doxas, K. \& Zeilik, M. 2003. Bioliteracy and Teaching Efficacy: What Biologists Can Learn from Physicists. Cell Biology Education, 2: 155-161.

Miller, J. D. 2011. To Improve Science Literacy, Researchers Should Run for School Board. Nature Medicine, 17 (1): 21-30.

Odja, A., H. \& Payu, C., S. 2014. Analisis Kemampuan Awal Literasi Sains Siswa pada Konsep IPA. Prosiding Seminar Nasional Kimia, ISBN : 978602-0951-00-3 Jurusan Kimia FMIPA Universitas Negeri Surabaya

Shwartz, Y. Ben-Zvi, R. \& Hofstein, A. 2006. The Use of Scientific Literacy Taxonomy for Assessing the Development of 
Chemical Literacy Among

High-School Students.

Chemistry Education Research

and Practice, 7 (4): 203-225.

Soobard, R. \& Rannikmäe, M. 2011.

Assessing Student's Level of

Scientific Literacy Using

Interdisciplinary Scenarios.

Science Education International

22 (2): 133-144

Uno, G. E. \& Bybee, R. W. 1994.

Understanding the Dimension

of Biological Literacy.

American Institute of Biological

Sciences, 44 (8): 553-557. 